Yayınlayan: Ankara Üniversitesi KASAUM

Adres: Kadın Sorunları Araştırma ve Uygulama Merkezi, Cebeci 06590 Ankara

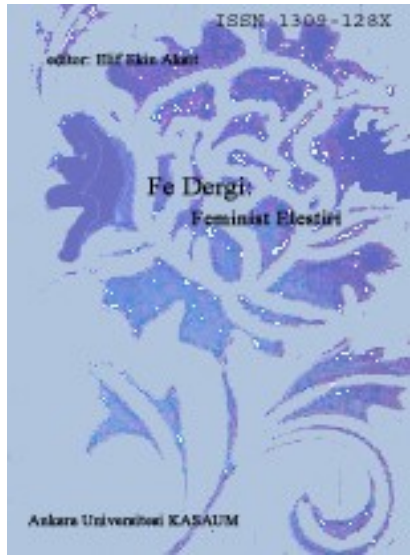

Fe Dergi: Feminist Eleştiri 4, Sayı 1

Erişim bilgileri, makale sunumu ve ayrıntılar için:

http://cins.ankara.edu.tr/

İki Kurgusal Metin Olarak Otobiyografi ve Tarih: Afet İnan Örneği

İknur Meşe

Çevrimiçi yayına başlama tarihi: 15 Haziran 2012

Bu makaleyi alıntılamak için: İlknur Meşe, "İki Kurgusal Metin Olarak Otobiyografi ve Tarih: Afet İnan Örneği" Fe Dergi 4, sayı 1 (2012), 28-41.

URL: http://cins.ankara.edu.tr/7_3.html

$\mathrm{Bu}$ eser akademik faaliyetlerde ve referans verilerek kullanılabilir. Hiçbir şekilde izin alınmaksızın çoğaltılamaz. 


\title{
İki Kurgusal Metin Olarak Otobiyografi ve Tarih: Afet İnan Örneği İlknur Meşe*
}

\begin{abstract}
Afet İnan Cumhuriyet döneminin yeni tarih anlaylşının temellerinin atılmasında ve kadın kimliğinin kurgulanmasında hem bir ideolog/misyoner gibi hizmet etmiş, hem de bunların şekillendirdiği bir Cumhuriyet aydını/kadını olmuştur. Çeşitli yerlerde Atatürk'ün direktifiyle başladığını söylediği tarih çalışmalarında kendisine verilen işleri başarıyla altından kalkılması gereken bir "milli vazife" olarak değerlendirmiştir. Afet İnan anılarında bu sürece, zaten çocukluğundan beri kendinde var olan tarih ve kültüre olan ilgi, okuma aşk ve potansiyelinin kaynaklık ettiğini belirtmişstir. Böylece Afet İnan, hayatının Atatürk'le tanıştıktan sonraki evresi ile önceki evresi arasında süreklilik kurarak kişisel tarihinin inşasından ulusal tarih inşasına gitmiş, bir Cumhuriyet tarihçisi ve kadını olarak yarattığ benlik izlenimini yüzeysellikten kurtarıp sağlam bir arkaplan üzerinde meşru göstermeye çallş̧ış̧tır.
\end{abstract} Anahtar Kelimeler: Afet İnan, Otobiyografi, Türk Tarih Tezi, Kadın ve Günlük Yaşamda Benliğin
Sunumu.

Two Fictional Texts, Autobiography and History: The Case of Afet İnan

Afet Inan has not only served in founding new history concept of Republic period and designating woman identity as an ideologist/missionary, but has been a Republic intellectual/woman via these things which helped her develop as well. Inan interpreted the tasks given during history studies, which she stated to begin with the directive of Atatürk, as a "national duty" to be resulted in success. Afet Inan indicated in her memoirs that the interest in history and culture, fondness for reading and her potency that she had had since her childhood formed the basis for this process. Therefore, Afet Inan achieved to lay the foundations of national history beginning with her individual history foundation through establishing a constant bond between the phases of her life before and after she became acquainted with Atatürk, and she aimed to legitimate her self impression she created as a Republic historian and woman through keeping it from superficiality.

Keywords: Afet Inan, Autobiography, Turkish History Thesis, Woman, and Representment of Self in Daily Life.

\section{Giriş}

Otobiyografik veya biyografik çalışmalar geçmişe yönelik bir benlik sunumu gayesiyle yapılır. Bu çalışmalarda benlik, bazen geçmiş olayların önüne çıkartılarak bazen olayların içinde anlatılarak, fakat her iki şekilde de belli bir izleyici kitlesi üzerinde istenilen/hedeflenen etkiyi yaratmaya yönelik bir biçimde sunulur. Geçmişin kurgusuna benliğin kurgusu dâhil edilir ya da daha doğrusu ikisi birbiriyle paralel olarak yeniden yaratılır. Geçmiş artık aktörlerin yazarla birlikte rollerini oynadıkları bir tiyatro sahnesine dönüşür. Yazar kronolojik tarihi gerçekliklerin sınırları dâhilinde, içeriğgini büyük oranda kendisinin beklenti ve izlenimlerine göre belirlediği bir oyunu aktörlere oynatır. Yazarla kurdukları ilişkiye göre kimi aktörlere iyi kimilerine de kötü bir rol verilmiştir. Kimilerine ise rol dahi verilmemiştir. Her tarihi olay da bu oyunda yer bulamayabilir. Hangi tarihi olayın ne şekilde yer alacağı yazarın oyun içindeki başat veya ikincil rollerine göre değiş̧mektedir veya yazarın adının geçmediği bir tarihi olay sırf bu yüzden göz ardı bile edilebilir.

Mikro sosyolojik bir kuram olarak "dramaturji" tam da anlatmak istediğimiz şeye yönelik ayrıntılı bir çözümleme sunmuştur. En bilinen temsilcilerinden Erving Goffman'ın "Günlük Yaşamda Benliğin Sunumu" adlı 1950’lerdeki gözlemlerine dayanarak yazdığı eseri, evrensel bir insani özellik olan "benliğin sunumu" olgusunun analizine odaklandığı için hem otobiyografik ve biyografik eserlerdeki benlik kurgusunu hem de günümüz dünyasındaki benliğin sunum şekillerini değerlendirmede bize yol gösterici olabilir.

Bu makalede amaç, Afet İnan'ın anılarında ${ }^{2}$ ve Atatürk etrafında yaşanan değişik konularda yazdığı eserlerde ${ }^{3}$ kendi konumunu ve rolünü nasıl yansıttığını, yani benliğini buralarda nasıl kurguladığını, okuyucuda ne tür bir benlik izlenimi yaratmaya çalıştı̆̆ını, o izlenimi ne oranda sabitleyip koruyabildiğini ve yaratmayı istediği izlenimde kendisinin ne kadar samimi olduğunu ortaya koyabilmektir. Makale boyunca Afet İnan'ın 
Türk Tarih Tezi, antropolojik çalışmaları gibi bizzat içinde canhıraş çalıştığı birçok konu sadece benlik kurgusu etrafında ele alınmış, etraflıca tartışılmaları bu makalenin kapsamı ve bağlamı dışında olduğu için başka bir makalenin konusu olmaya aday olarak ertelenmiştir.

\section{Yaşam Öyküsünde Benliğin Sunumu}

Belki Afet İnan İzmir'deki Reddi İlhak İlkokulu'na atanmasaydı ve Atatürk 11 Ekim 1925'te İzmir'e gidip o okulda öğretmenlerin verdiği çay ziyafetine katılmasaydı sade bir öğretmen ve vatandaş olarak yaşamını sürdürecekti ve büyük olasılıkla anılarını yazma gereği de duymayacaktı. Fakat Afet İnan o tarihte Atatürk'le tanışmış ve annesinin ailesinin Selanik'in Doyran kazasından olduklarını söyleyince Selanikli olan Atatürk'ün ilgisine daha bir mazhar olmuştur. Atatürk’ün eğitime verdiği önemi bildiği için, daha okumak niyetinde olduğunu belirtmiş ve o günden sonra da artık hep Atatürk'ün desteğini almıştır. Önce, Osmanlı'dan beri modernliğin dili olan Fransızcayı öğrenmek için Lozan'a, daha sonra da 1930'lu yıllardaki kültür politikalarına, özellikle tarih çalışmalarına hazırlık amacıyla Cenevre ve Sorbon Üniversitelerinde eğitim almaya gönderilmiştir. Ünlü bir antropolog ve etnolog olan ve Türkiye'ye her geldiğinde Atatürk'le de görüşen Prof. Dr. Eugene Pittard'ın Cenevre Üniversitesinde olmasını düşündüğümüzde Afet İnan'ın oraya tesadüfî gönderilmiş olduğunu söylemeyiz. Tesadüfî bir karşılaşmayla başlayan süreç sonraki adımları hesaplanarak atılan bilinçli bir serüvene dönüşmüştür. Ve böylece Afet İnan Atatürk'ün yakınında bulunarak Cumhuriyet döneminin dil ve tarih tezlerini içeren kültür politikalarının oluşturulmasında ve bunların eğitim aldığı yurtdışı üniversitelerinde katıldığı akademik ve bürokrat çevrelerinde tanıtılması yönünde gerçek bir "misyoner" gibi hizmet etmiştir. Fakat Afet İnan hayatının Atatürk’le tanıştıktan sonraki hareketli ve değişken yönünü, anılarının yer aldığı eserlere baktığımızda önceki yaşantısından bir kopma ya da kırılma olarak değil de daha çok süreklilik vurgusu etrafında izah ettiğini görürüz.

Burada Goffman’ın "bireyin işin başında çizdiği görüntü, onun, olduğunu iddia ettiği şeye bağlı kalmasını gerektirir." s sözünü hatırlatabiliriz. Afet İnan Atatürk’le tanıştıktan sonra üstlendiği Cumhuriyet kadını ve tarihçisi rolünü anahtar rol haline getirip diğerlerini geriye atmıştır. Sonra da çocukluğundan itibaren yaşadıklarından örnekler vererek yetişme tarzının ve zihin yapısının ta o zamanlardan kendisini bu role hazırladığını göstermeye çalışmıştır. Dolayısıyla geçmiş yaşantısını Cumhuriyet döneminde oynadığı aydın rolüne bağlı kalarak kurgulamıştır. Örneğin ilkokula gittiği zamanlarda babasının ve büyükannelerinin derslerinde kendisine yardımcı olduklarını, kendisine kitap ve gazete okutturduklarını, orman müfettişi olan babasının Fenike'ye teftişe gittiği bir seferinde kendisine Fransızca bir atlas getirdiğini ve ilk defa onun üzerinde Latin harflerini gördüğünü, öğrenmeye ve okumaya çalıştığını, anneannesinin İstanbul'a gittiği zamanlarda oradan kendilerine kitaplar gönderdiğini anlatmıștır. ${ }^{5} \mathrm{Bu}$ örneklerden Afet İnan'ın o zamanın şartlarına göre entelektüel diyebileceğimiz bir aile içinde büyüdüğünü anlayabiliriz. Hatta babasının memur olması dolayısıyla aile dostları arasında öğretmenlerin olduğunu, bu gibi kişilerin kendi gibi memur kızları arasında ilkokuldan sonra da eğitime devam etme ve öğretmen olma isteği uyandırdığını söylemiştir. Bir gün, ev işlerine yardımcı olan ve kendisiyle kardeşine bakan Nimet adında genç bir kızın hastalanması üzerine yine bir aile dostları olan doktoru çağırdıklarını, doktorun "haydi bakalım, sen de doktor olacaksın” diyerek muayenede kendisinden yardım istediğini, kendisinin de "doktor bey, kızlardan doktor olur mu? diye şaşkınlık içinde sorduğunu, tam da bu olayın yaşandığı 1922 yılında İstanbul Tıp Fakültesi’ne 7 kız öğrencinin kaydedildiğini belirtmiştir. ${ }^{6}$ Bunlar Afet İnan'ın kafasında eğitimine devam etme konusunda bir istek ve azim yaratmıştır. Hatta bir yerde, "Ben daima, daha yüksek okullarda olduğumu ve Avrupa'ya gittiğimi düşünürdüm"7 diyerek eğitimi söz konusu olduğunda ileriye dönük olarak ne kadar istekli ve azimli olduğunu belirtmiştir. Afet İnan görücü geldiğini anlattığı başka bir örnekte okuma ve öğrenme açlığının birçok şeyin önüne geçtiğini ve babasının da desteğini alarak evlenmek gibi konularla hiç ilgilenmediğini vurgulamıştır. ${ }^{8}$ Gerçekten de kendisi aktif eğitim aldığ Atatürk döneminde evlenmemiş, döneme göre hatta günümüzde bile devam eden anlayışa göre kadınlar için geç denilecek bir yaşta, 1940 yılında 32 yaşındayken evlenmiştir. Bütün bu örnekler onun Atatürk'le tanıştıktan sonraki akademik serüvenini meşru gösteren idealleştirilmiş bir zemin hazırlamaktadır. Afet İnan, tam da bundan dolayı Atatürk'e, örneğin İsmet İnönü’nün "velinimetim"9 diyecek tarzda duyduğu minnettarlıktan farklı bir minnettarlık duymuştur. O diğerleri gibi gözden düşüşler ve yükselişler yaşamamıştır. Onun Atatürk'le bir baba ve erkek-evlat ve kız ikili ilişkisi çerçevesinde, dönemin modernlik vurgusuna rağmen hiyerarşik görünümler arz eden, fakat her iki tarafın da kabulü söz konusu olduğu için kendi içinde tutarlı ve düzenli bir ilişski yaşadığını söyleyebiliriz. Atatürk bir baba figürü olarak onu belirli amaçlar doğrultusunda hareket etmeye sevketmiş, 
vazifeler ve sorumluluklar yüklemiş, kızı da layıkıyla bunların üstesinden gelmeye çalışmıştır. Bundan dolayı Afet İnan'ın anılarında ve başka eserlerinde, "Vazife verilmişti, başarmak icap ediyordu." 10 , "Çalışmalarımın büyük gayesi size yetişmek ve yurduma yararlı olmaktır. Bunun mükâfatını sizden aldıkça daha çok çalışmak ve layık olabilmek için uğraşıyorum." ${ }^{\prime 1}$ gibi cümleleri sıkça telaffuz ettiğini görebiliriz.

Belli durum tanımlarının istikrarını sağlamak amacıyla işbirliği içinde olan insanların bazı gerçekleri gizleme ve bastırma eğilimi içinde olmaları ${ }^{12}$ hali Afet İnan için de geçerlidir. Baba-kız ilişkisi bağlamında baba figürünün ve kendisinin sergilediği benliğin gerçekliğinin ve yarattığı izlenimin tehlikeye düşmesini sağlayacak bilgileri vermekten kaçınmış, sahnenin 'arka bölge' ${ }^{13}$ sine dair bilgileri denetime tabi tutarak sunmuştur. Bu yüzden Afet İnan Türk Tarih Tezi'ne ve Türk Tarih Kurumu'nun kurulmasına giden süreci ve kendisinin bunlara yönelik yurtdışından Atatürk'le yaptığı mektuplaşmaları anlatırken, Türkiye'de ırk içerikli/vurgulu bir anlayışla yürütülen antropolojik çalışmalardan ve bunların sonuçlarından bahsetmemiştir. Anılarını yazma amacını belirtirken bunlardan, "belirli konularda Türk uygarlığına ait çalışmalarım" diye üstü kapalı bir şekilde bahsetmiştir. Zaten anılarını yazmasının asıl amacının her şeyi anlatmak olmadığını şu cümlelerden anlamaktayız:

Anılarımı yayına hazırlarken şuna önem verdim. Yabancı kitaplarda ülkem hakkında gerçeğe uymayan sözlerin geçerli olmadığını göstermek için, belirli konularda Türk uygarlığına ait çalışmalarım olmuştur. Ayrıca, bugünkü bilimsel metotlarla dış ülkelere Türk ulusunun kültür verilerini anlatabilmek ve eleştirilere yanıt vermek istemişimdir. Kitapta bunları bulacaksınız. ${ }^{14}$

$\mathrm{Bu}$ tutumun yansımalarını daha birçok olayı değerlendiriş tarzında yakalamak mümkündür. Örneğin siyasi, ekonomik ve tarihi birçok konu ve meselenin, kendisinin 'Çankaya Üniversitesi' olarak değerlendirdiği Atatürk'ün sofrasında demokratik bir şekilde asker, bürokrat ve aydın kişiler tarafından enikonu tartışıldığını söylemiştir. Herkesin düşüncelerini açık açık ifade etme firsatı bulduğu bu ortamda rolünün konuşulanları not etmek olduğunu belirterek bu konuşmaların kendisi için çok yararlı ve öğretici olduğunu vurgulamıştır. ${ }^{15}$ Fakat konuşulan konuların kim tarafindan ve nasıl karara bağlandığı, bu kararlara aykırı bir sesin olup olmadığı veyahut kararların sorgulanmaya açık olup olmadığı konusunda sessiz kalmıştır. Dramaturjik terminolojiye göre Çankaya sofralarını herkesin belli bir durum tanımının yapılmasına yönelik performanslarını sergiledikleri bir sahne olarak düşünürsek, Afet İnan'ın bu sahnenin ve performansların gerçekliğine dair en ufak bir şüphesinin olmadığını söyleyebiliriz. Kendisinin rolüne dair de sorgulayıcı bir bakışı yoktur. Bunu, rolüne dair "milli vazife" 16 ifa ettiği değerlendirmesi yapmasından çıkarabiliriz. İşte tam da bu milli vazifesi gereği ne baba figürünü ne de kendisinden beklenenleri sorgulamamıştır. Aksine milli vazife diye bilip canla başla performanslarını sergilemeye çalışmıştır. Afet İnan, 6/7 Mart 1936'da Cenevre'den Atatürk'e gönderdiği bir mektubunda, "daimi çalışma yaşamının ayrıntılarını vermeyi ödev sayıyorum" ${ }^{17}$ demesiyle performansları hakkında hesap vererek babasının gözüne girmeye çalışan bir kız çocuğu gibi hareket etmiştir. Bu örneklerden Afet İnan'ın çalışmalarını Atatürk'ün direktifiyle kendisine verilen bir milli vazife gereği yaptığını rahatlıkla söyleyebiliriz. Fakat bu tespit bu kadar tutkuyla ve azimle çalışmasının kişisel boyutunu açıklamaya yetmez. Atatürk'ün direktifiyle başlayan tarih ve daha çok antropoloji eğitimi ve çalışmalarında, daha sonra Atatürk'ün gözüne girebilmek, kendini ona ispat edebilmek, genç yaşında birçok insanın elde etmediği rahat imkânları elinde tutabilmek, başarısıyla diğerleri arasından sivrilebilmek gibi birtakım içsel tutku ve arzuların etkisini de göz ardı etmemek gerekmektedir. Bunları tek tek açıklamak gerekirse, birincisi Afet İnan'ın gözünde Atatürk, vazifeyi veren ve başarıyla sonuçlanmasını isteyen, beklenti düzeyi yüksek bir insandır ve Afet İnan'da beklentilerini karşlayabilecek potansiyeli görmüştür. Zaten Afet İnan'ın Atatürk'le tanıştığı döneme kadar anlattıklarıyla yaratmaya çalıştığı benlik imajı, Atatürk'ün kendisine yaptığı yatırımların içi boş bir güvenden değil, Afet İnan'da gördüğü cevherden kaynaklandığı anlayışına dayanmaktadır. Hal böyle olunca Afet İnan, Atatürk'ün gözündeki kendine dair imajını dinç tutmak için elinden geleni yapmıştır. Çünkü biliyordu ki kendisine biçilen Cumhuriyet kadınının akademik hayattaki temsilcisi ve "kültür sembolü" 18 olma rolü çerçevesinde hareket ettikçe o çevrede kalabilirdi. Ama bu, Afet İnan'ın zorla bu role büründüğü anlamına gelmez. Gözü yükseklerde hırslı bir genç kadın için Atatürk'ün sunduğu imkânlar kendisini kanıtlaması yönünde mükemmel bir firsat olmuştur. İkincisi, Afet İnan dönemin sınırlı ekonomik ve eğitim koşulları dikkate alındığında birçok insanın elde edemeyeceği imkânlara sahip olmuştur. Lozan'a dil öğrenmeye gitmiş, yurtdışında eğitim almış, orada adını kitaplardan duyduğu bilim insanlarıyla tanışmış, almak istediği, ulaşmak istediği birçok kitaba ulaşmış, gezi ve inceleme amaçlı yurtdışı seyahatleri yapmış, dönemin seçkin asker, 
bürokrat ve akademisyenleriyle doğrudan ilişki kurmuş, Atatürk tarafından çeşitli amaçlarla tahsis edilmiş yat veya araba gibi araçlardan faydalanmıştır. Üçüncüsü, Afet İnan Atatürk'ün tek manevi kızı değildi. Bugün adını en çok bildiğimiz Afet İnan'la birlikte Sabiha Gökçen'dir. Kendilerinden beklenenleri yerine getirirken aynı zamanda birbirleriyle de yarışmış olabilirler. Başarılarını Atatürk'e göstermeye çalışırken, üstü kapalı bir şekilde birbirlerine karşı da bunu yapmışlardır. Amaç, başarılarıyla sivrilerek diğerinden daha çok babanın gözüne girebilmektir. ${ }^{19}$ Bu yüzden Sabiha Gökçen Dersim harekâtına katıldı̆̆ında ${ }^{20}$ ve Afet İnan da Türk tarih ve dil tezlerini savunurken ve bu doğrultuda Türkiye'de kafatası ölçmek suretiyle antropolojik tetkikler yaparken bunları sorgulamamıştır.

Böylece Afet İnan Atatürk’ten tasvip gördükçe ve yakın çevrenin de takdirini topladıkça ${ }^{21}$, sahnelediği performansları içselleştirip onların ürünü olarak benliğini inşa etmiştir. Çünkü Goffman'ın söylediği gibi sahnelenen benlik, ortaya konulan sahnenin nedeni değil ürünüdür. ${ }^{22}$ Afet İnan da rolüne kendini kaptırdıkça, onu oynanması ve canlandırılması, gerçek kılınması gereken bir şey haline getirdikçe rolü kimliğini/benliğini belirlemiş ve bildiğimiz Cumhuriyet kadını ve aydını Afet İnan ortaya çıkmıştır. Etkileşimci bir şekilde o rolünü oynadıkça Afet İnan olmuş, Afet İnan olmaya başladıkça da daha çok rolüne sahip çıkmıştır.

Afet İnan rolünü neredeyse hiçbir sorgulayıcı mekanizmaya tabi tutmadan içselleştirmesine rağmen, 1940’lı yıllardan sonra belki de dönemin havası gereği kabul görmeyeceğini veya radikal olduğunu düşündüğü kısımları hakkında sessiz kalmaya yönelik bir tutum sergilemiştir. ${ }^{23} \mathrm{Bu}$ sessiz kalışı bir vazgeçiş olarak değerlendirip “Acaba Afet İnan Atatürk döneminde savunduğu fikirlerden vazgeçmiş olabilir mi?" şeklinde bir soru sorabiliriz. $\mathrm{Bu}$ soruyu, özgürleşme isteğinden değișen dış dünya koşullarına, iç siyasete ve muhalif kesimlerin baskısına kadar varan birçok olası nedeni dikkate alarak cevaplayabiliriz. Birincisi, Atatürk'ün ölümüyle Afet İnan'ın üzerindeki baba figürünün etkisinin azaldığını ve yavaş yavaş ondan özgürleşmeye başladığını, özgürleştikçe de iç dünyasında eylemlerine yönelik sessiz sorgulamalara yöneldiğini varsayabiliriz. İkincisi, 1930'lu yıllarda Almanya, İtalya ve İspanya gibi ülkelerde varolan faşist ideoloji ve yönetimlerin yerini II. Dünya savaşından sonraki dönemde daha 1lımlı fikirlere bırakması ile rrkçı boyuttaki antropolojik çalışmaların yerine daha kültürel içerikli antropolojik araştırmaların geçtiğini söyleyebiliriz. Bu durumda Afet İnan'ın inatla Türk Tarih Tezi'nin dayanağı olan ırk vurgulu antropolojiyi savunması anlamsız olacaktır. Üçüncüsü, Atatürk devrimleriyle toplumun aurasının bozulduğunu savunan muhafazakâr kesimin, Atatürk'ün ölümüyle birlikte iç siyasette seslerini daha bir duyurur hale gelmelerinin de Afet İnan'a geri adım attırmış olacağını söyleyebiliriz.

Evet Afet İnan bazı konularda sessiz kalmışır, fakat Türk tarih ve dil tezlerini savunmaktan vazgeçmemiştir. Kendi rolünü ve aktivitelerini geriye çekip bu tezleri, "Atatürk’ün yeni tarih ve dil anlayışı", "Atatürk'ün emri ile...", "Böylece Atatürk...", "Atatürk’ün bu konudaki düşünceleri..." vb. şeklinde daha çok Atatürk merkezli bir anlatımla dillendirmeye ve savunmaya devam etmiştir. Atatürk'ün zaten tarih okumaları yapmaya başladığı dönemde, Afet İnan, devam ettiği İstanbul'daki Fransız Notre Dame de Sion okulunda okudukları coğrafya kitabında yer alan Türklerin sarı ırka mensup olduğu bilgisinin kendisini rahatsız etmesi üzerine Atatürk'e yönelttiği "Tarihte Türklerin vücude getirdiği medeniyetler nelerdir?" ${ }^{24}$ sorusu ile tarih çalışmalarının başladığını söylemiş̧tir. Burada tarih çalışmalarının başlamasına yönelik katkısını vurgulamaktan çekinmemiştir. Fakat akabinde, tarih ve dile yönelik bütün çalışmaların Atatürk'ün emriyle yapıldığını, kendisinin ise bu emirleri yerine getiren olduğunu belirtmiştir. ${ }^{25} 1937^{\prime}$ 'de başlayıp 1939 'da kendisinin doktora tezine veri sağlayan antropolojik çalışmalardan ne Türk tarih ve dil çalışmalarının nasıl başladığını ve devam ettiğini anlattığı kitaplarda ${ }^{26}$ ne de Atatürk'le olan mektuplaşmalarının da yer aldığı anılarında ${ }^{27}$ ve "Atatürk' ten Mektuplar" adlı kitapta ${ }^{28}$ ayrıntılı bir şekilde bahsetmemiştir. Sadece "Atatürk'ten Mektuplar"da, "İsviçre Cenevre Üniversitesindeki Öğrenim Devrimde Hazırladığım ve Yayınladığım Konular" başlığı ile kitabın sonunda yer alan "1930-1980 Yılları Arasında Kitap Olarak Çıkan Yayınlarımın Listesi” başlığı altında verdiği yayın listelerinde doktora tezinin 1939 ve 1941 Fransızca basımlarıyla 1947 Türkçe basımını vermiştir. ${ }^{29}$

Afet İnan'ın daha önceden savunduğu fikirlere dair sessizlik politikasının altında yatan şeyin kendisinin iradi kararının mı yoksa şartların zorlamasının mı veyahut da ikisinin eşit

ölçüde etkisinin mi olduğunu tam olarak bilemesek de, bunu, sergilenen izlenimi güvence altına almaya, hedef olması muhtemel bir açı̆̆ manevra olarak değerlendirebiliriz. Örneğin, 25-29 Eylül 1970'de yapılan VII. Türk Tarih Kongresi'nde sunduğu bildirisinin bir yerinde sarfettiği "Atatürk ırkçı olmamıştır ama, Türk halkının beyaz ırka mensup olduğunu, asrımızın ilmi delilleriyle ortaya konmasını istemiştir." sözüyle tezleri bilimsel amaçlı çalışmalar 
olarak değerlendirip meşru kılma çabasını görebiliriz. Bu yüzden yazılan her anının, yazarının bilinçli ve kasıtlı olarak kendini belirli bir şekilde ifade etmek ve olumlu bir izlenim yaratmak amaciyla bilgiyi denetime tabi tutarak yazdığını, tam da böyle olduğu için kurgusal bir yönünün olduğunu söyleyebiliriz.

\section{Tarihçi ve Kadın Kimliğinin Kurgulanışı}

Atatürk biyografilerinde, Atatürk'ün dehasının kanıtı olarak en çok matematik dersini sevdiğinin anlatılması gibi Afet İnan da sonradan edindiği tarihçi kimliğine kaynak olarak ilkokuldaki tarih derslerinden performanslarını örnek göstermiştir. Biga'da gittiği bir ilkokulda, tarih derslerini sevdiğini, padişahları sırasını şaşırmadan sayabildiğini, öğretmeninin de kendisini mükâfatlandırdığını anlatmıştır. Fakat ders kitabının, öğrenmek istediği ve hayal edebildiği büyük olayları vermede yetersiz kaldığını, 400 çadırlık bir halktan türeyen 600 yıllık Osmanlı Devleti'nin tarihinin dışına çıkılmadığını, aslında kendisinin hep Türk tarihinin daha uzak geçmişlere dayandırılabileceğini düşünmüş olduğunu söylemiştir. ${ }^{30}$ Kafasında nüve halinde olan bu gerçek, tayinlerinin çıtı̆̆ı Alanya'da bir gün birdenbire apaçı hale gelmiştir. Şöyle ki, babasıyla limanı gezerken orada bulunan kalenin Selçuklular zamanından kalma olduğunu öğrenmiş ve bunun üzerine sadece Osmanlıları anlatan, ondan önceki tarih hakkında suskun kalan dar tarih anlayışına kızgınlık duymuştur. 1937'de Alanya'ya tekrar gidişinde: "Bugünkü tarihi gerçekler ile dünkü, Osmanlı devrinde bizlere okutulan bilgiler arasında ne büyük fark var!...Osmanlı devri 600 yıllık tarihle yetiniyordu. Türkiye Cumhuriyeti Devleti, Türkün ve Türk yurdunun binlerce yıllık tarihinin temellerinde yükseliyor. Bugün, her Türk çocuğu bu gerçekle başbaşadır. O, bu yurda ezelden beri sahip oluşundan hız ve kuvvet alır." ${ }^{11}$ Burada Afet İnan Türk Tarih Tezi'ni dillendirmiştir. Bu teze göre, Orta Asya'nın otokton halkı Türklerdir. Buradan kuraklık vb. gibi nedenlerle dünyanın dört bir yanına dağılmış ve medeniyetler kurmuşlardır. Dolayısıyla bütün bir insanlık medeniyetinin temelini Türkler oluşturmuşlardır. Anadolu da bu Orta Asya'dan göç eden Türklerin yerleştiği öz be öz Türk yurdudur. Böylece Osmanlı devrindeki dar tarih anlayışından Afet İnan'ın ilkokuldan beri eksikliğini hissettiği daha geniş bir tarih anlayışına geçilmiştir. Afet İnan dönemin ünlü antropolog ve etnologlarının yazmış oldukları kitaplara, özellikle de Rene Gerin ve Eugene Pittard'ın Orta Asya'dan gelen brakisefal 1rkın Avrupa'ya medeniyeti getirdiği şeklindeki tezlerine dayanarak bu büyük sonuca ulaşmıştır ki bunu da 1932 yılında birincisi düzenlenen Türk Tarih Kongresi'nde savunmuştur. ${ }^{32}$ Gelen cılız eleştiriler karşısında tez genel kabul görmüş ve alkışlarla karşılanmıştır. 1937'de düzenlenen II. Türk Tarih Kongresi'nde ${ }^{33}$ de yaklaşık aynı şeyler dile getirilmiştir. Fakat bu sefer kongreye uluslar arası düzeyde katılım gerçekleşmiş, Afet İnan'ın hocası Eugene Pittard fahri başkan olarak konuşma yapmıştır. İki kongre de neredeyse muhalefetsiz bitmiştir. Hem kongredeki hem de daha sonraki eleştiriler Afet İnan'1 bu teze götüren kaynak bilgilerin çok da yeterli olmadığına, hatta onlardan böyle bir sonuca ulaşılamayacağına dairdir. ${ }^{34}$ Tarih adı altında daha çok antropolojik karakterli bu faaliyetlerin yanı sıra ikinci kongrenin yapıldığ 1 yıl Türkiye'de eşi görülmemiş ölçekte bir antropometrik araştırma yapılmıştır. Afet İnan'ın Atatürk'e yapılmasını önerdiği bu araştırma için Türkiye 10 ayrı kısıma ayrılmış ve toplam 64000 insan üzerinde kafataslarını ölçmek suretiyle tetkik yapılmıştır. Tetkiklerin sonuçlarını Afet İnan Cenevre Üniversitesi'nde yaptığı doktora tezinde kullanmıştır. Ulaşılan sonuç Türk Tarih Tezi'ni pekiştirecek şekildedir. Buna göre özetle, Orta Asya'dan Anadolu'ya gelerek buralarda ard arda çeşitli medeniyetler kuran insanlar arasında Türk olmaları açısından ırki aynılık vardır ve Türkler Avrupa'da Homo Alpinus adıyla anılan beyaz ırka mensuplardir. ${ }^{35}$

Afet İnan'1 bu kadar cüretkâr yapan nedir? veya daha 1lımlı soracak olursak, bu güvenli duruşun arkasında ne yatmaktadır? Milli kimlik inşası doğrultusunda Atatürk'ün kendisine verdiği vazife diye yanıtlamak birincil olmakla birlikte yeterli değildir. Bunun bir kısmının, anlattıklarına bakarak kendinden kaynaklandığını söyleyebiliriz. Anılarında hep okumak, Avrupa'ya gitmek, daha fazlasını öğrenmek ve ilerlemek hevesinde olduğunu, bu yüzden babasının da desteğiyle evliliğe sıcak bakmadığını, gelen görücüleri çevirdiğini anlatmış, bir yerde de, "sadece müfettişin kızı olarak değil, kendim, mesleğimle bir kişiliğe sahip olarak ulusuma hizmet etmeliydim." ${ }^{36}$ demiştir. Burada iki önemli unsur göze çarpmaktadır: Birincisi mesleğiyle anılmak, ikincisi mesleği aracılığıyla ulusa hizmet etmek.$^{37}$ Afet İnan tarih öğretmeni olarak başladığı işte akademisyenliğe doğru ilerlemiş ve aynı süreçte Cumhuriyet'in, kökleri uzak geçmişe dayalı, laik ve medeni karakterli bir ulus yaratma idealine hizmet etmiştir. Böylece Afet İnan kendi kişiliğini mesleğine yansıtmış her ikisini de Cumhuriyet ideali çerçevesinde tanımlamıştır. Burada Afet İnan’ın kendi kişiliğini bu ideal içinde erittiğini söyleyemeyiz. Aksine kendinde hep var olduğunu söylediği yurt ve tarih aşkının tam da bu ideale uygun geldiğini ve birbirlerini beslediğini söyleyebiliriz. 
14 Haziran 1935'te Ankara Üniversitesi'nin ilk fakültesi olarak kurulan Dil ve Tarih Coğrafya Fakültesi'nde öğretim görevlisi olması hakkında gelen öneriye karşılık, ancak lisans ve doktora yaptıktan sonra bu görevi alabileceğini söylemesine rağmen, 9 Ocak 1936'da yapılan açılış töreninde TTK Asbaşkanı sıfatıyla ilk dersi kendisi vermiştir. Bir üniversitenin açılış töreninde ilk dersi verecek, TTK'ın astbaşkanlığı sıfatına sahip olacak, kongrelerde ve yurtdısında Türk Tarih Tezi'ni milli vazife sayarak genç yaşında savunacak kadar yeterli görülen biri neden öğretim görevlisi olmak için daha henüz yeterli eğitimi almadığını beyan etmiştir? Hatta Afet İnan, Atatürk'ün manevi kızı sıfatıyla ve bütün bunları yapan biri olarak ön planda olmasına rağmen, Atatürk dönemi ve sonrası da dâhil olmak üzere ne TTK başkanı ne de milletvekili veya bakan olmuştur. Ancak Atatürk'ün vefatından bir yıl sonra doktorasını bitirip yurda döndüğünde Dil ve Tarih Coğrafya Fakültesi'nde Doçent vekili olarak ders vermeye başlamıştır. 1950'de profesör olmuş, Türkiye Cumhuriyeti ve Devrim Tarihi kürsü başkanı iken 1977'de kendi isteği ile emekliye ayrılmıştır. Afet İnan'ın kimseye dayanmadan, sadece mesleğiyle ayakta durma arzusu onu erken dönemde üniversite hocası, milletvekili veya bakan olmaktan alıkoymuştur. Eğitimini tamamlamadan, rüştünü ispatlamadan sırf Atatürk’ün eliyle bir yerlere gelmek veya öyle gözükmek veya alışık olmadığı/üstesinden gelemeyeceği siyasette yıpratılmak istememiş olabilir. Atatürk'ün de onca işte önde koşturduğu Afet İnan'ın daha yeterli eğitimi almadan milletvekili veya bakan olmasını istemediğini Hikmet Bayur'un şu sözlerinden anlıyoruz: "belki Afet Hanımı (bakan) yapardı, ama daha yetiştikten sonra. Yani ilk yaptığ 1 falso vermesin diye." 38 Önce milli vazifesini yerine getirerek rüştünü ispatlayacak, ehil olduktan sonra gerekli yerlere gelecekti. Bu ilk sorduğumuz sorunun cevabı olarak da görülebilir. Afet İnan babanın kızına verdiği emeklerin karşılığında, ona bir evlat olarak borcunu ödemek, onun güvenini boşa çıkarmamak ve bunlarla ilgili olarak etrafa da babanın duyduğu bu güveni hak ettiğini gösterebilmek adına daha bir cüretkâr ve daha bir radikal olmuştur. Çocukluğundan beri hissettiğini söylediği kendi başına varolabilme duygusunu hayata geçirmede bir firsat olarak tarihçi kimliğini ve rüştünü hem kendine ve Atatürk'e hem de etrafa -bu işte yaşlı ve tecrübeli olan aydın kesime- karşı ispat etmek amaçlı hareket etmiştir. Her ne kadar kendisi tarihçi kimliğinin bu radikal kısımlarına dair sessiz kalma davranışı sergilese de, Afet İnan'ın anılarını anlatırkenki takip ettiği izleği dikkate alarak onun rahatlıkla bu radikal tavra ulaştığını söyleyebiliriz. Anıları yaşantısının sessiz kaldığı bu kısmını -1930'lu yıllar- dahi destekler mahiyettedir.

Afet İnan sadece milli kimlik inşasında rol alan tarihçi kimliğiyle değil, yeni Türkiye'nin modern yüzünü temsil eden ‘Cumhuriyet kadını' kimliğiyle de ön plandadır. Hatta bunun en iyi ifadesini kızı Arı İnan'ın annesi için sarfettiği şu sözlerde bulabiliriz: “Afet İnan, Türk kadınının nasıl olması gerektiğine (çalışkanlığı, kültürü, davranışları ve kıyafetiyle) bir örnektir." 39 Afet İnan'ın, sadece Atatürk döneminde değil yaşamının sonuna kadar içselleștirmiş bir biçimde, bir yönüyle modern, eğitimli, kültürlü ama Tanzimat'tan beri yerilen ve Cumhuriyet modernleşmesinin de karakteristik yapısında olan fazlaca Batılılaşmış alafranga tarzdan uzak, iyi bir eş ve anne olma özellikleriyle Türk kadınına bir 'rol model' olması öngörülmüştür. ${ }^{40}$

Afet İnan Cumhuriyet döneminde yaptığı birçok şeyi çocukluğundan örnekler vererek temellendirirken, yalnızca kadınların seçme ve seçilme hakkına dair mücadelesinin tesadüf eseri başladığını anlatmıștır. Buna göre, Musıki Muallim Mektebi'nde Yurt Bilgisi dersinde bir seçim denemesi yaptırdıktan sonra bir erkek öğrencinin "yalnız zükur (erkek) oy verebilir. Siz bize kız arkadaşlarımıza da rey verdirdiniz." demesi üzerine ders çıkışında Marmara Köşkü’ne, Atatürk'ün yanına gelmiş ve ona kızgınlıkla durumu izah etmiştir. Atatürk de, kadın haklarıyla ilgili başka memleketlerde durumun nasıl olduğuna dair araştırma yaptıktan sonra Türk Ocağı'nda konferans vermesini istemiştir. ${ }^{41}$ Böylece 1930-1934 arasında kendini tesadüfî başlayan bir işle meşgul olurken bulmuştur. Sonuçta Afet İnan'ın büyük oranda dâhilinin olduğunu vurguladığ ${ }^{42}$ kadınlara seçme ve seçilme hakkını veren kanunlar çıkmıştır.

Prof. Dr. Afet İnan adlı kitabın “Afet İnan’ın Özel Yaşamı" "43 kısmında kızı Arı İnan’ın annesi hakkında anlattıklarına ve kitabın sonuna konulan fotoğraflara baktığımızda anlatımla fotoğrafların birbirini desteklediğini ve her ikisinin de Cumhuriyet modernleşmesinin kurguladığı ve Afet İnan gibi örneklerde hayata geçirmeye çalıştığı kadın modelini ortaya koyduğunu görebiliriz. Afet İnan iyi eğitim almış, kültürlü biridir. Bundan dolayı eğitimli bir kadının yapması gerektiği gibi makyajsız, takı takmaz ve sadedir. Bu onun iffetli olduğunun da bir göstergesidir. Ve yine bu yüzden erkeklerle olan ilişkilerinde hep mesafelidir. Eğitimli ve kültürlü olmasına rağmen evlilik yaşantısında eşinin izni olmadan hareket etmez. Savaş görmüş, yokluk çekmiş bir neslin evladı olduğu için israfa karşıdır. Cumhuriyet'in bir kısmı savaş ise bir kısmı kitaplardır. Afet İnan Atatürk'ün çok kitap okuduğunu çeşitli vesilelerle bulunduğu birçok yerde dile getirmiştir. Kendisinin de çocukluktan beri 
hevesli olduğu bir konudur bu. Bu yüzden kızının belirttiği gibi evlerinin en değerli ve en dokunulmaz yeri diğer evlerdeki gibi salon değil, annesinin kütüphanesinin yer aldığı çalışma odası olmuştur.

Afet İnan erkeklerin baskın olduğu bir alanda, tarih ve antropoloji ${ }^{44}$ alanında, Cumhuriyet tarafindan belirlenmiş kadın rolünün sınırları dâhilinde, bir erkeğin eliyle var olma mücadelesi vermiş̧ir. Fakat yazdıklarına baktı̆̆ımızda bunu çok da dert ettiğini görmüyoruz. Çünkü kendisinin zihin yapısında erkek ve kadın rollerinin kültürel birer kurgudan ibaret olduğuna ve hatta bu yüzden sorgulanabilir olduğuna dair bir algı yoktur. Kendisi de erkekler dünyasında ancak erkeksileşmiş ya da bazı kadın yazarların Cumhuriyet'in kadın modeline dair söyledikleri gibi "kadınsı olmayan", "cinsiyetsiz" ${ }^{45}$ bir kadın olarak var olunacağını biliyordu. Cumhuriyet seçkinleri eğitimli, kültürlü, modern, vatansever bir yurttaş, laik, Avrupa adabı muaşereti bilen vb. gibi özelliklere sahip olması anlamında bir erkek modeli kurguladığı gibi bundan daha fazla, kendisinin organik bir uzantısı olacak şekilde, fakat ev yaşantısı ile kamusal yaşantı, geleneksel olan ile modern olan, erkek rolü ile kadın rolü arasında denge kurabilen bir kadın modeli de kurgulamıştır. Burada Cumhuriyet erkeği bir anlamda özgür olabilirken Cumhuriyet kadını anne, milli kültürün taşıyıcısı ve aktarıcısı ve erkeğin organik bir uzantısı olması anlamlarında çok çeşitli bağlayıcı unsurlarla sınırlandırılmış ve bu yüzden kolaylıkla ideolojik, politik ve kültürel bir aygıt haline dönüştürülmüştür. Bunun sonuçlarına baktığımızda, kadın kimliği iktidarın merkezinde olan erkekler tarafından inşa edildiği için ataerkil yapının kırılmadığını, buna bağlı olarak kadının ev içindeki konumunun ve rolünün değişmediğini, zaten yapılan kadın tanımının da sadece dönemin şartları gereği eğitim imkanlarına daha rahat ulaşabilen şehirli bir tabakayı etkilediğini söyleyebiliriz. Fakat yine de Cumhuriyet kadını, yeni nesillere eğitim, hukuk, tıp vb. alanlarda meslek sahibi olabilmesi noktasında bir rol model olmuştur. Akşit'in belirttiği gibi kadınların eğitimi onları yeni ve doğrudan bir baskı alanına soktuğu gibi, özgürleştirici alanlara sevk olmaları ihtimalini de taşır. ${ }^{46}$ Evet, kadınların eğitimi ataerkil zihniyetin devamlılığını sekteye uğratmamış, hatta bu sefer onu, yeni eğitim kurumlarında eğitimli kadınlar üzerinden işlerlik kazanarak modern bir görüntüye de büründürmüştür, fakat bu kadınlar eğitim, hukuk, tıp vb. alanlarda meslek sahibi olmaları nedeniyle kamusal alanda daha bir görünürlük kazandıkları gibi daha sonraki yıllarda o mesleği icra edecek diğer kadınlara rehber olabilecek şekilde, o mesleğe dair kadınsal deneyim ve bilgi birikimi de oluşturmuşlardır.

\section{Sonuç}

Aslında bir otobiyografi yazmak ile bir milletin tarihini yazmak arasında kayda değer benzerlikler vardır. Her ikisi de geçmişe müdahale etme girişimi olarak görülebilir. Geçmiş her ikisinde de bugünden yola çıkılarak denetimli bir şekilde, yaratılmak istenen imaja ve verilmek istenen izlenime uygun olarak ve son kertede etkilenmesi beklenen belli bir insan topluluğu için yeniden kurgulanır. Böylece hem kişisel hem de ulusal tarih, yazılan şeyin nedeni değil ürünü olarak belirir. Bu durumda artık kişisel ile ulusal tarih yaşanılanı aşıp yapılabilen bir şey haline gelir. Dramaturjik terminolojiyi kullanacak olursak, sahne kavramını yazılan otobiyografik eser ve ulusal tarih kitapları olarak; oyuncu kavramını yazar olarak; seyirciyi yazarın kitap aracılığıyla etkilemek istediği kesim olarak; performans kavramını da yazarın seyirciyi etkilemeye yönelik anlattığ tüm etkinlikleri olarak değerlendirebiliriz.

"İster dürüst bir oyuncu gerçeği iletmeye çalışıyor olsun, isterse dürüst olmayan bir oyuncu bir yalan iletmeye çalışyor olsun, her ikisi de performanslarına uygun ifadelerle can vermeye, yaratılan izlenimin inanılırlı̆ıını zedeleyecek ifadelere performanslarında yer vermemeye ve seyircinin amaçlanandan farklı anlamlar çıkarmaması için özen göstermeye mecburdur." ${ }^{\text {"7 }} \mathrm{Bu}$ nedenle Afet İnan'ın anılarına baktığımızda, Atatürk döneminde kendisine atfedilen Cumhuriyet tarihçisi ve kadını rollerine uygun gelecek şekilde bir söylem ürettiğini görebiliriz. Afet İnan üstlendiği rollerine uygun bir benlik oluşturmuştur. Sonra bu benliğe ta çocukluğundan başlayıp destekleyici örnekler vererek tarihsel bir zeminde süreklilik kazandırmaya çalışmıştır. Anılarında yaratmaya çalıştı̆̆ kişisel tarihiyle içinde bulanarak üretilmesine bizzat katıldığı ulusal tarih, mevcut gerçekliğe uygun bir geçmiş oluşturma anlamında iki kurgusal metin olarak birbirleriyle paralellik göstermektedir. Nasıl ki Afet İnan'ın tarihe ve Türk kültürüne olan ilgisiyle birlikte okumaya olan merak1 çocukluğundan geliyorsa, Türk milletinin de medeni olma vasfi ile beyaz ırka mensubiyetliği Orta Asya gibi uzak bir geçmişten gelmektedir. Yine nasıl ki Afet İnan doktora tezinden ve antropolojik çalışmalarından anılarında bahsetmemiş, bilerek unutma/unutturma politikası gütmüşse, aynı şekilde Orta Asya'dan yeni Türkiye'ye doğru milli tarihsel yollar döşenirken Osmanlı İmparatorluğu için de bir unutma/unutturma politikası güdülmüştür. Diğer bir paralellik de, iki tarih anlatısına (kişisel ve ulusal) siyasal ve ideolojik öğelerin hâkim 
olmasıdır. Böylece Afet İnan'ın kişisel tarih anlatısı özel olmaktan çıkıp kamusala ve oradan da ulusal tarihe bağlanmıştır.

Afet İnan, Türk Tarih Tezi’ne dair söylemi hayatının sonuna kadar çeşitli yerlerde dillendirirken, bu tezin ırk boyutunu destekleyen ve Cenevre Üniversitesi'nde yaptığı doktora tezinin konusunu da teşkil edecek olan antropolojik çalışmalardan 1940'lı yıllardan sonra bahsetmemiştir. Anılarında ve Atatürk'le mektuplaşmalarının olduğu eserlerde bu konu yer almamıştır. Bunu bir geri adım veya vazgeçiş olarak değerlendirmek için elimizde yeterli delil yoktur. Fakat Goffman'ın buraya ekleyeceğimiz şu sözleri bizi sorgulayıcı bakıştan uzaklaşmamaya davet etmektedir: "Bir uçta, oyuncu kendini oyununa tamamen kaptırmış olabilir; sahnelediği gerçeklik izleniminin gerçek gerçeklik olduğuna samimi şekilde ikna olabilir. Seyircisi de sergilenen gösteriye böylece ikna olduğunda, en azından o an için, yalnızca sosyologlar veya toplumdan hoşnutsuz birisi sunulanın "gerçekliğinden" kuşku duyacaktır." 48

Afet İnan makalenin son kısmında tartıştığımız gibi Cumhuriyetin yaratmak istediği kadın imgesinin bir sembolüdür. Kendisi hem bu imge tarafından şekillenen bir nesne hem de bu imgeyi şekillendiren bir özne olmuştur. Özne olma halini -ne kadar eleştirirsek eleştirelim- inat ve azimle yaptığı tarih çalışmalarında görebiliriz. Ne kadar Atatürk'ün isteğiyle başlamış olsa bile kendisinin bu konudaki istek ve tutkusunu anılarında görebiliriz. Afet İnan'ın kendisinin tarihçi kimliğine yönelik belki bir tereddüdü yoktur, ama Türk Tarih Kurumu'nun bir dergisi olan Belleten'de onun 1985 yılındaki vefatına ve vefat yıldönümlerine dair herhangi bir anma yazısının çıkmaması da bize Belleten çevresinin onun tarihçiliği konusunda tereddütleri olduğunu göstermektedir. ${ }^{49}$ Aslında bunu iki şekilde yorumlayabiliriz. Birincisi tarih biliminin cinsiyetçi tutumu; ikincisi ise tarih anlayışında yaşanan kırılma dolayısıyla 1930'lu yıllarda Türk Tarih Tezi'ni savunmuş biri olarak Afet İnan'ın da geri planda tutulması. 
*Aksaray Üniversitesi, Sosyoloji Bölümü.

${ }^{1}$ Erving Goffman, Günlük Yaşamda Benliğin Sunumu, Çev. Barış Cezar (İstanbul: Metis Yay., 2009).

Goffman bu çalışmasının bir tiyatro oyunu ile aynı bakış açısına sahip olduğunu söylemiştir. Toplumsal yaşantıda her gün karşılaşılan durumlarda bir bireyin kendini ve faaliyetlerini başkalarına nasıl sunduğu, başkalarının kendisi hakkında oluşturduğu izlenimi nasıl yönlendirdiği ve denetlediği, onların karşısında performansına devam ederken neler yapabileceği ve yapamayacağ üzerinde durmuştur. Bu yüzden "performans", "sahne arkası", "rol”, "seyirciler" gibi tiyatroya dair terimler kullanmıştır. Fakat Goffman yaşamı bir tiyatroya benzetirken ihtiyatlıdır. Çünkü ona göre sahne yapmacık şeyler sunar, yaşam daha gerçek ve genelde pek de iyi prova edilmemiş şeyler sunar. Belki bundan da önemlisi, sahnede oyuncu bir karakter kılığına girerek kendini başka oyuncular tarafından yansitılan karakterlere sunar; seyirci etkileşimde hayati öneme sahip ama gerçek yaşamda var olmayan üçüncü bir taraf oluşturur. Gerçek yaşamda, bu üç taraf sıkıştırılarak ikiye indirilir: Bir kişinin oynadığı rol mevcut diğerlerinin oynadığ rollere göre biçilir, ancak bu diğer insanlar aynı zamanda seyirciyi de oluşturur.

Goffman çalışmasında kullandığı kavramları, ne anlamda kullandığını göstermek amacıyla ufak ufak tanımlamalar yapmıştır. Örneğin "etkileşim"i(yani yüz yüze etkileşim) kabaca fiziksel olarak aynı ortamda bulunan bireylerin karş1lıklı olarak birbirlerinin eylemleri üzerindeki etkileri olarak, "Performans"1 belli bir durumda belli bir katılımcının diğer katılımcılardan herhangi birini etkilemeye yönelik tüm etkinlikleri şeklinde tanımlamıştır. Bir performans sırasında gözler önüne serilen önceden belirlenmiş ve başka durumlarda da sergilenebilecek ya da oynanabilecek eylem kalıbını ise "rol" veya "rutin" olarak adlandırmıştır.

${ }^{2}$ A. Afetinan, Atatürk'ten Mektuplar (Ankara: TTK Basımevi, 1989); Ar1 İnan (Haz.), Prof. Dr. Afet İnan (İstanbul: Remzi Kitabevi, 2006). Arı İnan'ın verdiği bilgiye göre, Afet İnan vefatından önce anılarının Atatürk'le tanışmaya kadarki 1908-1925 arasını kapsayan I. kısmını yazmış, fakat ömrü yetmediği için gerisi yarım kalmıştır. Arı İnan duyduğu sorumluluk duygusundan dolayı annesinin çeşitli kitaplarında yazdıklarını bir araya getirerek anılarını tamamlamaya çalışmıştır. Afet İnan'ın kısa bir yaşam öyküsü daha önce "Geçen Günlerimden” başlığı altında 'Atatürk'ten Mektuplar'ın birinci basımı olan 1981'de yayınlanmıştır. 2005'de ilk baskısı yapılan Prof. Dr. Afet İnan adlı kitapta bu yaşam öyküsü daha ayrıntılı bir halde anlatılmıştır.

${ }^{3}$ Afet İnan, Ellinci Yılda Tarihten Geleceğe, Türkiye İş Bankası Kültür Yay. (Ankara: TTK Basımevi,1973); Türkiye Cumhuriyeti ve Türk Devrimi, TTK Yay., Ankara 1998; Atatürk Hakkında Hatıralar ve Belgeler (İstanbul: Türkiye İş Bankası Kültür Yay., 2007).

${ }^{4}$ Günlük Yaşamda Benliğin Sunumu, 23.

${ }^{5}$ Bkz. Atatürk’ten Mektuplar, 4.

${ }^{6}$ Prof.Dr. Afet İnan, 72-73.

${ }^{7}$ Prof.Dr. Afet İnan, 86; Afet İnan Bursa Kız Okulu'nda okurken öğretmeni mezun olmadan önce son ödev olarak göreve atanma dilekçesi örneği yazmalarını istemiştir. Kendisi ise ilkokul öğretmeni olarak mezun olduğu okulu, Lozan Üniversitesi'nden mezun olmuş gibi gösterip ona göre bir dilekçe yazmıştır:

\section{“Bursa Milli Eğitim Müdürlüğ̈̈ Yüksek Katına,}

(İsviçre) Lozan Üniversitesi'nin 1340 (1924) yılı mezunlarındanım. Lozan'dan hareket ettiğim zaman evvela emelim bütün Anadolu'yu ve kendi ülkemizi, beş yıldır görmediğim vatanımı dolașmak, seyahat etmek idi. Aslında bütün Anadolu'muzun köșelerini gezdim ve Avrupa mesdeniyetine karşı ne kadar geri kaldığımızı hayretle gördüm. Bursa'ya geldiğim zaman bütün okullarını gezdim. Ve bu arada yeni açılan Kız Lisesi Okulu'nu gezdiğim zaman, bütün Anadolu'nun her köşesinde olduğu gibi burada da, öğretmen bulmak hususunda birçok derslerin açık olduğunu gördüm. Ve işte hiçbir zaman öğretmen olmak hevesinde değil iken, parlak fikirli mini mini yavrularımıza karşı kalbimde bir yurtseverlik duygusu uyand.

Yurduma karşı daha başka türlü hizmet etmek emelinde idim. Fakat bizim ülkemizde öğretmenlik kadar kutsal bir şey olmayacă̆ını gördüm. Adı geçen lisenin felsefe, fen eğitimi öğretmenliğine talip oluyorum. Atanmamı rica ederim efendim.

31.4.1341 (1925)

Lozan Üniversitesi Mezunlarından

Bursa Orman Müdürü Kızı Afet Hakkı"

Öğretmeni yazının üzerinde düzeltmeler yaptıktan sonra kendisini çağırıp, "Siz şimdi ilkokul öğretmeni olarak mezun oluyorsunuz. Ona göre bir istida (dilekçe) yazacaksınız.” demiştir. Afet İnan, Lozan Antlaşması dolayısıly adının çok duyulduğu bu şehrin kendisinde okumak için bir heves uyandırdığını, aslında Bursa Kız Okulu'nu bitirdikten sonra ya yüksek öğretmen okulunda ya da Avrupa'da öğrenimini sürdürmek niyetinde olduğunu belirtmiştir. Prof. Dr. Afet İnan, 86-87.

${ }^{8}$ Prof. Dr. Afet İnan, 74.

${ }^{9}$ İsmet İnönü, Konuşma, Demeç, Makale, Mesaj ve Söyleşiler 1933-1938, Haz. İlter Turan (Ankara: TBMM Kültür, Sanat ve Yayın Kurulu Yay., 2003), 350.

${ }^{10}$ Prof. Dr. Afetinan, “Türk Tarih Kurumu 40 Yaşında”, Belleten, Cilt:XXXV, Ekim 1971, Sayı:140 (Ankara: TTK Basımevi, 1971), 21.

11 Prof.Dr. Afet İnan, 160.

${ }^{12}$ Günlük Yaşamda Benliğin Sunumu, 106.

${ }^{13}$ Goffman arka bölge kavramını, belli bir performans tarafından çizilen izlenimle çelişen bir görüntünün yer aldığ bölge olarak tanımlamıştır. Günlük Yaşamda Benliğin Sunumu, 112.

${ }^{14}$ Prof.Dr. Afet İnan, 8.

${ }^{15}$ Prof.Dr. Afet İnan, 102. 


\footnotetext{
${ }^{16}$ Prof.Dr. Afet İnan, 132.

${ }^{17}$ Prof.Dr. Afet İnan, 168.

${ }^{18}$ Şevket Süreyya Aydemir, Tek Adam Mustafa Kemal, 3. Cilt (İstanbul: Remzi Kitabevi, 1966), 494.
}

${ }^{19}$ Bunu iki kadının anılarında görebiliriz. Ne Afet İnan ne de Sabiha Gökçen anılarında birbirlerine yer vermedikleri gibi Atatürk'ten başka bir erkeğin adından da bahsetmemişlerdir ve her ikisi de Atatürk'ün ölümünden sonra evlenmişlerdir. Olayları sadece kendilerinin birebir Atatürk'le olan ilişkileri merkezinde anlatmışlar, sanki diğerleri yokmuş ya da diğerleri bir hayal de bir kendilerinin ve Atatürk'ün gerçekliği varmış gibi davranmışlardır. Sabiha Gökçen değerlendirmesi için bkz. Nazan Aksoy, Kurgulanmış Benlikler, Otobiyografi, Kadın, Cumhuriyet (İstanbul: İletişim Yay., 2009),148-149; Ayşe Gül Altınay, "Dünyanın İlk Kadın Savaş Pilotu Sabiha Gökçen", Vatan, Millet, Kadınlar, Der. Ayşe Gül Altınay (İstanbul: İletişim Yay., 2000):246-279.

${ }^{20} \mathrm{Bu}$ konudaki benzer bir değerlendirme için bkz. Kurgulanmış Benlikler, 143-150.

${ }^{21}$ Yapılan mektuplaşmalardan Atatürk'ün yakın çevresinin de Afet İnan'1 yurtdışında aldığı eğitim, verdiği konferanslar vb. gibi konularda çalışmalarını yakından takip edip desteklediklerini anlıyoruz. Bu mektuplardan bir örnek:

"Afet,

Son mektubunu bu gece aldım, önce bana gelmiş olan İn̈nü ve onunla beraber bulunan Numan'a (Menemencioğlu) Inönü okudu. Ondan sonra sofraya davet ettiğim bütün tarih ve dil üyelerine okuttum. Dirik de (Kazım) hazırdl, hepsi çok memnun oldular; ben de çok sevindim.

Selam, gözlerinden öperim.

K.Atatürk” Prof.Dr. Afet İnan, 163.

${ }^{22}$ Günlük Yaşamda Benliğin Sunumu, 235.

${ }^{23}$ Bundan bahseden bir makale için bkz. Zafer Toprak, “Atatürk, Eugene Pittard ve Afet İnan, En Büyük Antropolojik Anket”, Toplumsal Tarih Dergisi, Sayı: 205 (İstanbul: Tarih Vakfı Yurt Yay., Ocak 2011): 20-30.

${ }^{24}$ Ellinci Y1lda Tarihten Geleceğe, 11.

${ }^{25}$ Örneğin tarih ve dil çalışmalarının nasıl başladığını anlattığı kaynaklarda, Afet İnan, Atatürk’ün Türk Ocakları'nın VI. Kurultayı'nda üzerinde çalıştıkları yeni tarih anlayışına dair konferans vermesi için kendisine "Bu mesele üzerinde çalışacak ve Türk tarihinden bahsedeceksin." dediğini anlatmıştır. Bunun üzerine Afet İnan, "Görev verilmişti, başarmak gerekiyordu." şeklinde yorum yapmıştır. Atatürk Hakkında Hatıralar ve Belgeler, 260; Prof. Dr. Afet İnan, 109; Ellinci Y1lda Tarihten Geleceğe, 19; Atatürk’ten Mektuplar, 12.

${ }^{26}$ Bkz. Ellinci Y1lda Tarihten Geleceğe, 17-25. Bu kitapta yer alan, Türk Tarih Kurumunun nasıl kurulduğunu anlattı̆ğ "Türk Tarih Kurumu 40 Yaşında” başlıklı yazısı Afet İnan'ın Türk Tarih Kurumunun 40. yıldönümünde verdiği konferansta sunduğu metindir. Aynı metin Belleten Dergisi'nde de yayınlanmıştır: Cilt: XXXV, Ekim 1971, Sayı: 140 (Ankara: Türk Tarih Kurumu Basımevi, 1971), 519-529; Atatürk Hakkında Hatıralar ve Belgeler, 255-275.

${ }^{27}$ Prof. Dr. Afet İnan, 106-111; 117-124. Anılarının 3. Bölümünde "Cenevre'de Öğrenim Yılları” başlığ1 altında Doktora tezinin konusundan kısaca bahsetmiştir: "Doktora tezimin konusu ise, Türkiye tarihinin genel durumu ve antropolojik veriler üzerinde yapılan ankete göre Türk milletinin, dünya milletleri arasındaki yerini bilimsel esaslara göre saptamak idi. Bu çalışmamı ilk önce tez olarak Fransızca kendim bastırmıştım (1939); sonra da Cenevre Üniversitesi, tezlerin ikinci cildi olarak 1941'de kendi kitapları arasında yayınlamıstır. Bu tezimle, Fransız Lisesi'nde okuduğum ders kitabındaki bilgiler bozulmuş ve Türk ulusunun durumu, günümüzün bilimsel delillerine göre saptanmış oluyordu..", 154. Afet İnan'ın doktora tezinin Türkçe basımı ise 1947 yılında TTK tarafından yapılmıștır. Bkz. Atatürk’ten Mektuplar, 69;91. Prof. Dr. Afet İnan adlı kitapta kızı Arı İnan tarafından eklenen Afet İnan ile Atatürk arasında gerçekleşen mektuplaşmalar, Afet İnan'ın Cenevre'den 3 Aralık 1935'de gönderdiği mektup ile başlamış, Atatürk'ün İstanbul, Savanora Yatı'ndan 14 Nisan 1938'de gönderdiği mektup ile bitmiştir. Bu bölüme seçilerek konulan mektuplara baktığımızda, bu tarihler arasında Türkiye'de başlatılmış olan antropolojik çalışmadan neredeyse hiç bahsedilmemiş olduğunu görürüz. Sadece Afet İnan'ın Cenevre'den 18 Kasım 1936'da gönderdiği mektupta şöyle bir değinilmiştir: "Anthropologie dersine epey hazırlıklı girmiş oldum. Okuduğum kitapları söylediğim zaman profesör çok memnun oldu. İleride yapmayı düşündü̈̆̈̈m tezimin konusunu Pittard çok beğendi. Anket için de bazı önerilerde bulunacak. Onunla olan çalışmamı Türkiye üzerine istiyor. Onu henüz saptamadım, ĕger belge bulursam yine Etiler üzerinde yapmak belki ilginç olur.”, 172-173. Burada yapmayı planladığını söylediği tezi ve anket çalışmasından ilerleyen sayfalarda hiç bahsetmemiştir.

${ }^{28}$ Bu kitapta, Prof. Dr. Afet İnan adlı kitabın Atatürk'le mektuplaşmalar kısmında yer almayan, Cenevre'den 29 Ararlık 1937 yılında gönderdiği bir mektupta Afet İnan, "Asıl tezim için de arada çalışıyorum. Henüz yazmak için bir hazırlı̆̆ım yok. Yalnız anket meselesi için istatistik müdürü ile arada görüşüyorum. Son görüşmemizde anket planlarının tanzimi üzerinde çalıştık. O bitirip bana Paris'e gönderecek.” Atatürk'ten Mektuplar, 64.

${ }^{29}$ Bkz. Atatürk’ten Mektuplar, 69; 90-91. Yayın listelerini verdikten sonra doktora tezi için bir de küçük açıklama yapmıştır: "Bu doktora tezimi hazırlamaktaki amacım, bugün Türkiye'de yaşayan milletimizin yeni antropolojik incelemelere göre durumunu tespit etmektir. Aynı zamanda Türkiye tarihinin arkeolojik devirlerinde çıkan kalıntıları ile, ölçüler bakımından, 
mukayese ederek Türkiye'deki bu eski medeniyetlere sahip oluşumuzu ispatlamak." 71.

${ }^{30}$ Prof.Dr. Afet İnan, 58.

${ }^{31}$ Prof.Dr. Afet İnan, 67-68.

${ }^{32}$ Afet İnan, "Tarihten Evel ve Tarih Fecrinde”, I. Türk Tarih Kongresi, Maarif Vekaleti, (2 Temmuz 1931): 18-41. Afet İnan'ın sunumunun son kısmı Türk Tarih Tezi’ni özetlemektedir. Buna göre:

“Artık bizi, tetkike sevkeden sorgunun cevabını verelim!

Ortaasiyanın Otokton halkı Türktür.

$\ldots$

Kafasm ve vicdanm, en son terakeki şulelerile güneslendirmeye karar vermis olan, bugünün Türk çocuklar, biliyor ve bildirecektir ki, onlar, 400 çadirl bir aşiretten değ̈l, on binlerce yullik, Ari, medeni, yülksek bir irktan gelen, yülksek. kabiliyetli bir millettir.

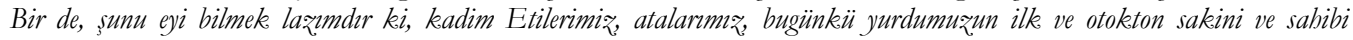
olmuşlardrr. Türklügün merkeezini Altaylardan Anadolu-Trakyaya getirmişlerdir. Türk. Cumburiyetinin sarslmaz temelleri bu öz yurdun cökmez kayalarndadr.

Bu mukaddes yurdun öz varisi, Türkiye Cumhuriyetinin yllmaz harisi, o büyük, yüksek, asil Türk kavminin bugünkü genç ve dinç çocuklarıdır; biziz!", "Tarihten Evel ve Tarih Fecrinde”, 41.

${ }^{33}$ Bu kongrede Afet İnan, "Türk Tarih Kurumunun Arkeoloji Faaliyeti” bașlıklı tebliğ sunmuștur. İkinci Türk Tarih Kongresi, İstanbul, 20-25 Eylül 1937, Kongrenin Çalışmaları, Kongreye Sunulan Tebliğler (İstanbul: Kenan Matbaası, 1943): 8-15.

${ }^{34}$ Örneğin Fuat Köprülü I. Türk Tarih Kongresi’nde, Batı medeniyetini yaratan ırkın menşei hakkındaki araştırmaların henüz yeterli miktarda olmadığını söyleyerek Afet İnan'ın konuşmasını eleştirmiştir. Kongrenin ilerleyen zamanlarında eleştiri alması üzerine eleştirisini geri çekmiştir. I. Türk Tarih Kongresi, 47; 79. Bir diğerine örnek olarak Arı İnan'ın hazırladığı Tarihe Tanıklık Edenler adlı kitabındaki Hikmet Bayur ve Afet İnan arasındaki söyleşiyi gösterebiliriz:

“Hikmet Bayur: Şimdi siz "Türk Tarihinin Ana Hatları” diye bir kitap yazmıştınız.

Afet İnan: Siz onu tenkit etmiştiniz.

Hikmet Bayur: Evet. Bana gönderdi Tevfik mütalaa sordu. Yalnı bir şeye iliştim. Hititlerin Türklüğ̈̈ meselesi var. Orada deniliyor ki, filanca muharrir Hititlerin Türk olduğunu yazmıştır. O Kitap da bende vardı. Baktım. Orada deniliyor ki, işte filanca Hititlerin Türk olduğunu söylüyorsa da, böyle değil. ” (İstanbul: Çağdaş Yay., 1997), 303.

${ }^{35}$ Afet İnan, “Türkiye Halkının Antropolojik Karakterleri Üzerinde Büyük Anket ve Umumi Neticeleri”, Belleten, Cilt: IV, Sayı:13, II. Kanun, 1940 (Ankara TTK, 1994), 51. I. Türk Tarih Kongresi’nde Fuat Köprülü’nün Türk Tarih Tezi’ne yönelik, az veriyle çabuk ulaşılmış sonuçlar olarak yaptığı eleştirinin bir benzerini, yıllar sonra, Afet İnan'ın doktora tezinin 1947 TTK basımından sonra Halil Demircioğlu'nun eleştirisinde bulabiliriz. Demircioğlu'nun 19 sayfalık eleştirisinin toplandığı yer, Afet İnan'ın bugünkü halk ile bugüne kadar Anadolu topraklarında yaşamış olan halklar arasında kurduğu ırki bağlılığın, elde ettiği az sayıdaki iskelet kalıntılarına dayandırıldığı için bilimsel olmaktan ziyade a priori kabuller üzerine inşa edildiği şeklindedir. Demircioğlu, bu haliyle eserin ne tarih ne de antropoloji ile ilgisinin olmadığını söyleyerek Afet İnan'ı keskin bir şekilde eleştirmiştir. Bkz. Halil Demircioğlu, "Antropoloji ve Tarih (Bir kitap vesilesiyle)" A.Ü.D.T.C.F. Dergisi, Cilt: 6, Sayı: 1-2 (1948): 49-67. Afet İnan bu konularda konuşmaktan imtina etse bile bu eleştiri karşısında sessiz kalmamıştır. Kendisinin yazdığı yazı için bkz. Afet İnan, "Türkiye Tarihi ve Antropolojisi Üzerine", A.Ü.D.T.C.F. Dergisi, Cilt: 7, Sayı: 1 (1949): 203-236.

${ }^{36}$ Prof.Dr. Afet İnan, 87.

${ }^{37}$ Cumhuriyet döneminde kadına biçilen rollerden birisi de modern, meslek sahibi bir kadın olmasıydı. Bu nedenle kadının bazı uzman mesleklerde eğitim alması Kemalizm tarafından desteklenmiştir. Gökçe Bayrakçeken Tüzel'in 1910lu yıllarda doğan hukuk, tıp ve akademisyenlik gibi profesyonel mesleklerde çalışan kadınlarla yaptığı görüşmelerden çıkarımlarını aktardığı makalesinde, bu kadınları ülkeye hizmet etmek konusunda motive eden şeyin sadece Cumhuriyet ruhu ve ideolojisi olmadığını, eğitimini aldıkları mesleğin edindirdiği mesleki idealler olduğunu söylemiştir. Bkz. "Kemalizm, Profesyonelizm ve Ataerkil Tezahürler”, Toplum ve Bilim Dergisi, Sayı:114 (İstanbul: Birikim Yay., 2009), 39-40. Bu nedenle Afet İnan'1 da dahil ederek bu kadınların kendilerini mesleklerine adadıklarını, onun ortaya çıkardığı/dayattığı mesleki bilinç gereği ülkelerine hizmet ettiklerini söyleyebiliriz.

${ }^{38}$ Tarihe Tanıklık Edenler, 338.

39 Prof.Dr. Afet İnan, 13

${ }^{40}$ Bunu Atatürk’ün çeşitli vesilelerle ‘Türk kadını'nın nasıl olması gerektiğine dair söylediği sözlerden çıkarabiliriz. Bkz. Arı İnan (Der.), Düşünceleriyle Atatürk (Ankara: Türk Tarih Kurumu Basımevi, 1999), 90-93. Bu ideal kadın portresini Atatürk 'Cumhuriyet kadını' olarak adlandırmamıştır, bunun üzerine kafa yoran Atatürk dönemi aydınları da öyle 
adlandırmamışlardır, fakat bu kadın tipinin yeni Türkiye'nin devlet şekline ve ideolojisine uygun olacak biçimde tanımlanmasından yola çıkarak yeni kadına 'cumhuriyet kadını' da denilebilir ki, Cumhuriyet döneminde yaratılmak istenen kadın tipini değerlendiren ve eleştiren feminist yazarlar genellikle cumhuriyet kadını demeyi tercih etmişlerdir. Örneğin bkz. 75 Yilda Kadınlar ve Erkekler (İstanbul: Tarih Vakfi Yay., 1998).

${ }^{41}$ Tarihe Tanıklık Edenler, 283-288.

${ }^{42}$ Hülya Adak Cumhuriyet'in kuruluş yıllarına, yani 1920ler ve 30lara odaklanan kadın otobiyografilerini incelediği makalesinde, bazı kadınların kendilerini istisnai roller içinde anlattıklarını, örneğin Halide Edib'in otobiyografik eserlerinde dönemin tek kadın edebiyatçısı ve milli mücadelenin tek kadın kahramanı kendisiymiş gibi bir izlenim verdiğini, aynı şekilde Afet İnan'ın, bizim de belirttiğimiz gibi, Nezihe Muhiddin, Halide Edib ve Latife Hanım gibi öncüleri görmezlikten gelip kendisini 1920 ve 30ların tek feminist aktivisti olarak gösterdiğini belirtmiştir. Bkz. "Oy Hakkını Savunan İmparatorluk Kadınları, Cumhuriyetin Kızları: Kadın Oto/biyografi Yazarlarının Anlattı̆̆ Milli Tarihtir (1918-1935)" Edebiyatın Omzundaki Melek, Edebiyatın Tarihle İlişkisi Üzerine Yazılar, Haz. Zeynep Uysal (İstanbul: İletişim Yay., 2011), 265. Zaten CHP dışındaki birçok kuruluşun dönemin otoriter tek parti zihniyeti gereği var olmasına izin verilmediği bir ortamda, Afet İnan'ın, merkezde yer alan birisi olarak kadın hareketinin Osmanlı'dan gelen uzantısını dillendirmesi beklenemezdi. Bu açıdan bakarsak kendisini kadın hakları konusunda öncü görmesi daha anlaşı1ır hale gelebilir.

${ }^{43}$ Bkz. s.222-237 arası; Türkiye Cumhuriyeti ve Türk Devrimi, 170-171.

${ }^{44}$ Türk Tarih ve Dil Tezleri örneğinde olduğu gibi ulus-devletler biçimlenirken tarih, antropoloji ve daha birçok sosyal bilim alanı, bu yeni devletin biçimine ve ona uygun vatandaş yetiştirmesine olanak sağlayacak biçimde bilgileri üreten, bu özelliğiyle de siyasi ve ideolojik bir misyon yüklenmiștir. Ulus-devletin eril bir kurum olması dolayısıyla tarih yazımının kendisi de eril bir icraat olarak karşımıza çıkmaktadır. Ulus-devletin eril yapısı hakkında bkz. Cynthia Enloe, "Feminizm, Milliyetçilik ve Militarizm", Vatan, Millet, Kadınlar, 189-212; Joane Nagel, "Erkeklik ve Milliyetçilik: Ulusun İnşasında Toplumsal Cinsiyet ve Cinsellik", Vatan, Millet, Kadınlar, 58-94; Genel olarak bilimlerin eril karakteri hakkında bkz. Evelyn Fox Keller, Toplumsal Cinsiyet ve Bilim, Çev. Ferit Burak Aydar (İstanbul: Metis Yay., 2007); Özelde tarih biliminin erilliği hakkında bkz. Fatmagül Berktay, Tarihin Cinsiyeti (İstanbul: Metis Yay., 2010).

${ }^{45}$ Bkz. Deniz Kandiyoti, Cariyeler, Bacılar, Yurttaşlar (İstanbul: Metis Yay., 1997), 76; Ayşe Kadığlu, Cumhuriyet Irradesi Demokrasi Muhakemesi (İstanbul: Metis Yay., 1999), 31; Meyda Yeğenoğlu, Sömürgeci Fanteziler (İstanbul: Metis Yay., 2003), 174; Yeşim Arat, “Türkiye'de Modernleşme Projesi ve Kadınlar”, Türkiye'de Modernleşme ve Ulusal Kimlik, Edit. Sibel Bozdoğan, Reşat Kasaba (İstanbul: Tarih Vakfı Yurt Yay., 1998), 94.

${ }^{46}$ Elif Ekin Akşit, "Haydi Kızlar Okula: Kızların Eğitimi, Kadınların Bilgisi ve Kamusal Alan Tartışmaları”, Toplum ve Bilim Dergisi, Sayı:114 (İstanbul: Birikim Yay., 2009), 10-11.

${ }^{47}$ Günlük Yaşamda Benliğin Sunumu, 72

${ }^{48}$ Günlük Yaşamda Benliğin Sunumu, 29.

${ }^{49}$ Afet İnan'ın 1985 yılındaki vefatından önceki Belleten sayılarına baktığımda bazı kişilerin vefat veya doğum yıldönümlerine yönelik özel sayılar yapıldığını gördüm. Örneğin Belleten'in Cilt: XLVIII, Sayı: 189-190, Ocak-Nisan 1984 (Ankara: TTK Basımevi, 1985) sayısı Prof. Dr. Gotthard Jaschke anısına armağan edilmiştir; Cilt: XLVI, Sayı: 182, Nisan 1982 (Ankara: TTK Basımevi, 1982) sayısı 1973-1982 arası TTK Başkanlığı yapmış olan Ord. Prof. Dr. Enver Ziya Karal'ın anısına adanmıștır; Cilt: XLIII, Sayı: 170, Nisan 1979 (Ankara: TTK Basımevi, 1979) sayısı doğumunun 80. yıldönümü nedeni ile Uluğ İğdemir'e armağan edilmiştir. 1988 yılından itibaren Belleten dergisinin içindekiler kısmına "Nekroloji” kısmı eklenmiştir. Burada tarih ve ilgili alanlara hizmeti dokunmuş kişilerin vefatlarına veya vefat yıldönümlerine yönelik anma yazıları yazılmıştır. Dergiyi 2000'li yıllardaki sayılarına kadar incelemiş olmama rağmen, Türk Tarih Kurumu'nun kuruluşuna emeği geçen biri olarak Afet İnan adının hiç geçmediğini gördüğümde oldukça şaşırdım.

\section{Kaynakça}

Adak, Hülya. "Oy Hakkını Savunan İmparatorluk Kadınları, Cumhuriyetin Kızları: Kadın Oto/biyografi Yazarlarının Anlattı̆̆ Milli Tarihtir (1918-1935)” Edebiyatın Omzundaki Melek, Edebiyatın Tarihle İlişkisi Üzerine Yazılar, Haz. Zeynep Uysal (İstanbul: İletişim Yay., 2011): 253-282.

Aksoy, Nazan. Kurgulanmış Benlikler, Otobiyografi, Kadın, Cumhuriyet (İstanbul: İletişim Yay., 2009).

Akşit, Elif Ekin. "Haydi Kızlar Okula: Kızların Eğitimi, Kadınların Bilgisi ve Kamusal Alan Tartışmaları”, Toplum ve Bilim Dergisi, Sayı:114 (İstanbul: Birikim Yay., 2009): 7-26. 
Altınay, Ayşe Gül. “Dünyanın İlk Kadın Savaş Pilotu Sabiha Gökçen”, Vatan, Millet, Kadınlar, Der. Ayşe Gül Altınay (İstanbul: İletişim Yay., 2000): 246-279.

Arat, Yeşim. “Türkiye'de Modernleşme Projesi ve Kadınlar”, Türkiye'de Modernleşme ve Ulusal Kimlik, Edit. Sibel Bozdoğan, Reşat Kasaba (İstanbul: Tarih Vakfi Yurt Yay., 1998), 94.

Aydemir, Şevket Süreyya. Tek Adam Mustafa Kemal, 3. Cilt (İstanbul: Remzi Kitabevi, 1966).

Berktay, Fatmagül. Tarihin Cinsiyeti (İstanbul: Metis Yay., 2010).

Demircioğlu, Halil. “Antropoloji ve Tarih (Bir kitap vesilesiyle)” A.̈̈.D.T.C.F. Dergisi, Cilt: 6, Sayı: 1-2 (1948): 49-67.

Enloe, Cynthia. "Feminizm, Milliyetçilik ve Militarizm”, Vatan, Millet, Kadınlar, Der. Ayşe Gül Altınay (İstanbul: İletişim Yay., 2000): 189-212.

Goffman, Erving. Günlük Yaşamda Benliğin Sunumu, Çev. Barış Cezar (İstanbul: Metis Yay., 2009).

İnan, Afet. "Tarihten Evel ve Tarih Fecrinde”, I. Türk Tarih Kongresi, Maarif Vekaleti (2 Temmuz 1931): 1841.

“Türkiye Halkının Antropolojik Karakterleri Üzerinde Büyük Anket ve Umumi Neticeleri”, Belleten, Cilt: IV, Sayı:13, II. Kanun, 1940 (Ankara: TTK, 1994): 39-51.

."Türk Tarih Kurumunun Arkeoloji Faaliyeti”, İkinci Türk Tarih Kongresi, İstanbul, 20-25 Eylül 1937, Kongrenin Çalışmaları, Kongreye Sunulan Tebliğler (İstanbul:Kenan Matbaası, 1943): 8-15.

“Türkiye Tarihi ve Antropolojisi Üzerine”, A.Ü.D.T.C.F. Dergisi, Cilt: 7, Sayı: 1 (1949): 203-236.

."Türk Tarih Kurumu 40 Yaşında”, Belleten, Cilt:XXXV, Ekim 1971, Sayı:140 (Ankara: TTK Basimevi, 1971): 519-529.

Ellinci Yılda Tarihten Geleceğe, Türkiye İş Bankası Kültür Yay. (Ankara: TTK Basımevi, 1973). .Atatürk'ten Mektuplar (Ankara: TTK Basımevi, 1989).

Türkiye Cumhuriyeti ve Türk Devrimi (Ankara: TTK Yay., 1998).

.Atatürk Hakkında Hatıralar ve Belgeler (İstanbul: Türkiye İş Bankası Kültür Yay., 2007).

İnan, Arı. Tarihe Tanıklık Edenler (İstanbul:Çağdaş Yay., 1997).

.(Der.), Düşünceleriyle Atatürk (Ankara: Türk Tarih Kurumu Basımevi, 1999). 
Prof. Dr. Afet İnan (İstanbul: Remzi Kitabevi, 2006).

İnönü, İsmet, Konuşma, Demeç, Makale, Mesaj ve Söyleşiler 1933-1938, Haz. İlter Turan (Ankara:TBMM Kültür, Sanat ve Yayın Kurulu Yay., 2003).

Kadığlu, Ayşe. Cumhuriyet İradesi Demokrasi Muhakemesi (İstanbul: Metis Yay., 1999).

Kandiyoti, Deniz. Cariyeler, Bacılar, Yurttaşlar (İstanbul: Metis Yay., 1997).

Keller, Evelyn Fox. Toplumsal Cinsiyet ve Bilim, Çev. Ferit Burak Aydar (İstanbul: Metis Yay., 2007).

Nagel, Joane. "Erkeklik ve Milliyetçilik: Ulusun İnşasında Toplumsal Cinsiyet ve Cinsellik”, Vatan, Millet, Kadınlar, Der. Ayşe Gül Altınay (İstanbul: İletişim Yay., 2000): 58-94.

Toprak, Zafer. “Atatürk, Eugene Pittard ve Afet İnan, En Büyük Antropolojik Anket”, Toplumsal Tarih Dergisi, Sayı: 205, (İstanbul: Tarih Vakfı Yurt Yay., Ocak 2011): 20-30.

Tüzel, Gökçe Bayrakçeken. “Kemalizm, Profesyonelizm ve Ataerkil Tezahürler”, Toplum ve Bilim Dergisi, Say1:114 (İstanbul: Birikim Yay., 2009):27-50.

Yeğenoğlu, Meyda. Sömürgeci Fanteziler (İstanbul: Metis Yay., 2003).

75 Yılda Kadınlar ve Erkekler (İstanbul: Tarih Vakfı Yay., 1998). 